J. Amer. Soc. Hort. Sci. 115(6):901-905. 1990.

\title{
The Role of Leaf Development on Anthurium Flower Growth
}

\author{
Jingwei Dai'and Robert E. Paull ${ }^{2}$ \\ College of Tropical Agriculture and Human Resources, University of Hawaii at Manoa, Honolulu, \\ HI 96822
}

Additional index words. bleach problem, development, photosynthesis, leaf growth, flower growth, Anthurium andraeanum

\begin{abstract}
The growth and development of Anthurium andraeanum Andre cv. Kaumana flower before and after emergence from the subtending leaf base was studied. Eighty days before emergence, the anthurium flower was $=0.3$ cm long, enclosed by two tightly rolled stipules at the base of the subtending leaf petiole. During the rapid elongation stage of the leaf petiole, the flower $(0.8$ to $1.0 \mathrm{~cm}$ long) entered a period of slow growth 40 to 60 days before flower emergence. After the subtending leaf blade unfurled and had a positive photosynthetic rate, flower growth resumed. Spathe color development started $=\mathbf{2 8}$ days before emergence when the flower was $=\mathbf{5 0 \%}$ of the emergence flower length $(4.5 \mathrm{~cm})$. At flower emergence, the spathe, excluding the lobes, was $=75 \%$ red. The lobes did not develop full redness until 7 to 10 days after emergence. Peduncle growth was sigmoidal with the maximum growth rate 21 days after emergence. Spathe growth is characterized by a double sigmoid curve. The young, growing, subtending leaf blade had a negative net photosynthetic rate. Removal of this leaf blade advanced flower emergence by 18 days. The soft green leaf ( 25 to 30 days after leaf emergence) had a slightly positive measured net photosynthetic rate, and the removal of this leaf resulted in flower emergence 11 days earlier. A mature subtending leaf had the highest measured net photosynthetic rate, and its removal had little effect on flower emergence. The subtending leaf acted as a source of nutrients required for the developing flower. Altering the source-sink relationship by leaf removal accelerated flower emergence, probably by reducing the slow growth phase of the flower.
\end{abstract}

Anthurium, characterized by its showy spathe, is the most important flower crop in Hawaii (Hawaii Agr. Statistics Service, 1988). The commercial flower consists of a modified leaf (spathe) that subtends a cylindrical inflorescence called a spadix (Marutani, 1984). This in florescence is covered with numerous tiny true flowers (Higaki and Watson, 1967). The heart-shaped spathe is $=7 \mathrm{~cm}$ wide $\mathrm{x} 10 \mathrm{~cm}$ long and produced in a cycle of flowerleaf-flower-leaf (Walker and Smith, 1978). Flowers are produced throughout the year after the juvenile phase has passed (Kamemoto and Nakasone, 1963). Flower is used here and throughout this manuscript to refer to the commercial product, made up of the spadix, spathe, and peduncle.

In late 1981, a flower development disorder, referred to as "bleach", was first described in commercial anthurium fields (Nishijima, 1981). Impaired color development occurred in the spathe lobe area in mild cases of the disorder. In severe cases, the entire flower, including the spadix, showed signs of reduced color development, stunting, distortion, and necrosis (Bushe et al., 1987).

The disorder symptoms suggested abnormal flower development and seemed to be a problem associated with the development of anthocyanins before the flower emerges from the subtending leaf petiole base. We studied in detail the sequence and timing of spathe, spadix, and lobe development before and after flower emergence, and when anthocyanin synthesis occurs.

Received for publication 24 July 1989. Hawaii Institute of Tropical Agriculture and Human Resources Journal Series no. 3395. We appreciate the technical assistance provided by Theodore Goo, and Kazu Ginoza for providing some of the plant materials. Mention of a trademark or proprietary product does no constitute a guarantee or warranty of a product by the Univ. of Hawaii, and does not imply its approval to the exclusion of other products that may also be suitable. The cost of publishing this paper was defrayed in part by the payment of page charges. Under postal regulations, this paper therefore must be hereby marked advertisement solely to indicate this fact.

'Graduate Student, Dept. of Horticulture.

${ }^{2}$ Plant Physiologist, Dept. of Plant Molecular Physiology,

\section{Materials and Methods}

Plant growing conditions. Terminal cuttings (160, two-leaved, 30 to $40 \mathrm{~cm}$ long) from 3- to 4-year-old plants of anthurium $\mathrm{CV}$. Kaumana were obtained from a commercial grower on the island of Hawaii in June 1987. They were harvested in the morning, received at Honolulu that afternoon, potted into wood-shavings in 3.6-liter pots and grown under $73 \%$ shade cloth. The average photon flux density was 55 to $70 \mu \mathrm{mol} \cdot \mathrm{s}^{-1} \cdot \mathrm{m}^{-2}$. The daytime averages were 20 to $22 \mathrm{C}$ during January to April, rising to 24 to $28 \mathrm{C}$ from April to June in 1988, when the plants were used for this study. Nights were at 16 to $22 \mathrm{C}$. Irrigation was supplied automatically from overhead sprinklers for 5 min twice a day, and relative humidity was in the range of $60 \%$ to $95 \%$ for the growth study period. Osmocote $(18 \mathrm{~N}-2.6 \mathrm{P}-10 \mathrm{~K})$ fertilizer was supplied (15 g/pot) once a month. Foliar-60 (National Research and Chemical Co., Gardena, Calif.), a micronutrient source, was applied to the medium $(=0.75 \mathrm{~g} / \mathrm{pot})$ once every 3 weeks. Six healthy plants with an average height (soil to top of the leaves) of $42 \mathrm{~cm}$ and with $=3$ to 4 fully expanded leaves $(25$ $\mathrm{cm}$ in length, $13 \mathrm{~cm}$ in width) were chosen at random for this study.

Plant growth measurements. Plants with a newly emerging second flower were tagged. Petiole length (length from the base of the petiole to the leaf) and leaf blade length (leaf lobe to leaf tip) were measured when the leaf had emerged from the leaf sheath. The leaf blade was compared with the color chips on the RHS Colour Chart (Royal Horticultural Society, 1966). The firmness of the leaf blade was subjectively determined by hand and ranked as soft, hard, and very hard. The subtending leaf growth and development were used to predict flower bud growth. This developmental index meets the requirement of having recognizable morphological changes with time and was nondestructive (Erickson, 1976).

The length of the flower stem or peduncle (length from the stem to the junction of the peduncle and flower spathe) and length of spathe (junction to spathe tip) and of spadix were 
measured. Growth rate per day was determined as change in length or width divided by seven. Spadix length was measured after spathe unfurling, and maturity was estimated as the percentage (proportion of spadix showing color change) of mature minute flowers on the spadix. Immature minute flowers were yellow on the spadix, whereas mature minute flowers were white.

Leaf photosynthesis. The rate of $\mathrm{CO}_{2}$ fixation of the leaves 14, 28, and 42 days after leaf emergence was determined with a LI-6000 Portable Photosynthesis System (LI-COR, Lincoln, Neb.) in shadehouse conditions between 1:00 and 3:00 PM. Three to six leaf blades were measured for each stage and the means of the net photosynthesis rate and the standard deviations were calculated by the LI-6000.

Flower bud growth evaluations. At weekly intervals, eight leaves were dissected from leaf emergence to the next flower emergence. Flower length (stem base to flower tip), peduncle length (from the stem base to the junction of spathe), spadix length (bottom to the tip of the spadix), spathe length (junction of the spathe with peduncle to the tip of the spathe), spathe width (widest part of the spathe, usually across the junction of peduncle, spathe, and spadix), and lobe width (from a line drawn from the junction of the, spathe with the peduncle across the spathe to the tip of the lobe) were measured. The spathe and lobe widths could only be measured after unfurling of the spathe following heating in hot water $(=75 \mathrm{C})$ for $10 \mathrm{~min}$. The flower age was estimated as the number of days before and after flower emergence. The means of the length and standard deviations were calculated. Since the flowers were young and soft, cell division was estimated using the acetocarmine stain smear technique (Jensen, 1962).

Subtending leaf removal. Subtending leaf blades from six plants, one leaf on each plant, were removed at the junction of petiole and leaf blade 7 to 14,25 to 30 , and 45 to 50 days after leaf emergence. The day of flower emergence from the petiole base was recorded. When flowers emerged from comparable control plants (plants without subtending leaf removal), the length of each part of the inflorescence was measured, and the means and standard deviations determined.

\section{Results}

Flower growth before emergence. Flower emergence from the stipules of the subtending leaf was regarded as day $O$. The newly unemerged leaf $(=3.5 \mathrm{~cm}$ long) subtended the smallest measurable flower $(0.3 \mathrm{~cm}$ long) 80 days before flower emergence (BFE) and 21 days before subtending leaf emergence (BSLE). Mitotic figures were detected at this time in these flowers. The flower lengthened to $0.8 \pm 0.1 \mathrm{~cm}$ in $=21$ days (Fig. 1A). When the new leaf was about to emerge from its sheath, the length of the flower was $0.9 \mathrm{~cm}, 15 \%$ of its length at flower emergence (Table 1). The growth rate of this period was 0.02 $\mathrm{cm} \cdot \mathrm{day}^{-1}$ (Fig. 1B). From subtending leaf emergence until day 14 after subtending leaf emergence (ASLE), flower growth rate slowed for $=20$ days (Fig. 1A). During this nearly stationary phase, the growth rate was $0.01 \mathrm{~cm} \cdot \mathrm{day}^{-1}$ (Fig. 1B). Few mitotic figures were observed, although vascular tissue and stomata began to appear at this stage.

Flower bud growth recommenced following the stationary stage, 28 days ASLE and 28 days BFE (Fig. 1A). The flower gradually increased from 0.9 to $1.5 \mathrm{~cm}$, with a growth rate of $0.043 \mathrm{~cm} \cdot \mathrm{day}^{-1}$ (Fig. 1B). Twenty-eight to 42 days after leaf emergence, 28 to 14 days BFE, the flower increased from 1.5 to $2.5 \mathrm{~cm}$ (Fig. 1A), with a growth rate of $0.6 \mathrm{~mm} \cdot$ day $^{-1}$ (Fig. lB). The flower length at this time was $=50 \%$ of the emerged
Table 1. The relationship between subtending leaf growth and anthurium flower bud growth inside the subtending leaf petiole base.

\begin{tabular}{|c|c|c|c|c|}
\hline $\begin{array}{c}\text { Days } \\
\text { after } \\
\text { leaf } \\
\text { emergence }^{z}\end{array}$ & $\begin{array}{c}\text { Flower bud } \\
\text { developmental } \\
\text { stages }\end{array}$ & $\begin{array}{c}\text { Final } \\
\text { petiole } \\
\text { length }^{y} \\
(\%)\end{array}$ & $\begin{array}{l}\text { Leaf } \\
\text { color }\end{array}$ & $\begin{array}{c}\text { Flower } \\
\text { length } \\
(\mathrm{cm})\end{array}$ \\
\hline 0 & Cell division & --- & --- & $0.3-0.8$ \\
\hline 0 to 14 & Slow growth & $40-75$ & Olive brown & $0.8-1.0$ \\
\hline 14 to 28 & Cell elongation & $75-90$ & Light green & $1.0-1.5$ \\
\hline 28 to 42 & Anthocyanin synthesis & $90-95$ & Green & $1.5-2.5$ \\
\hline 42 to 56 & Emergence & $95-100$ & Dark green & $2.5-4.5$ \\
\hline
\end{tabular}

${ }^{2}$ The data are based on the analysis of six shoots.

${ }^{y}$ The data refer to the percentage of final length achieved at the times indicated.

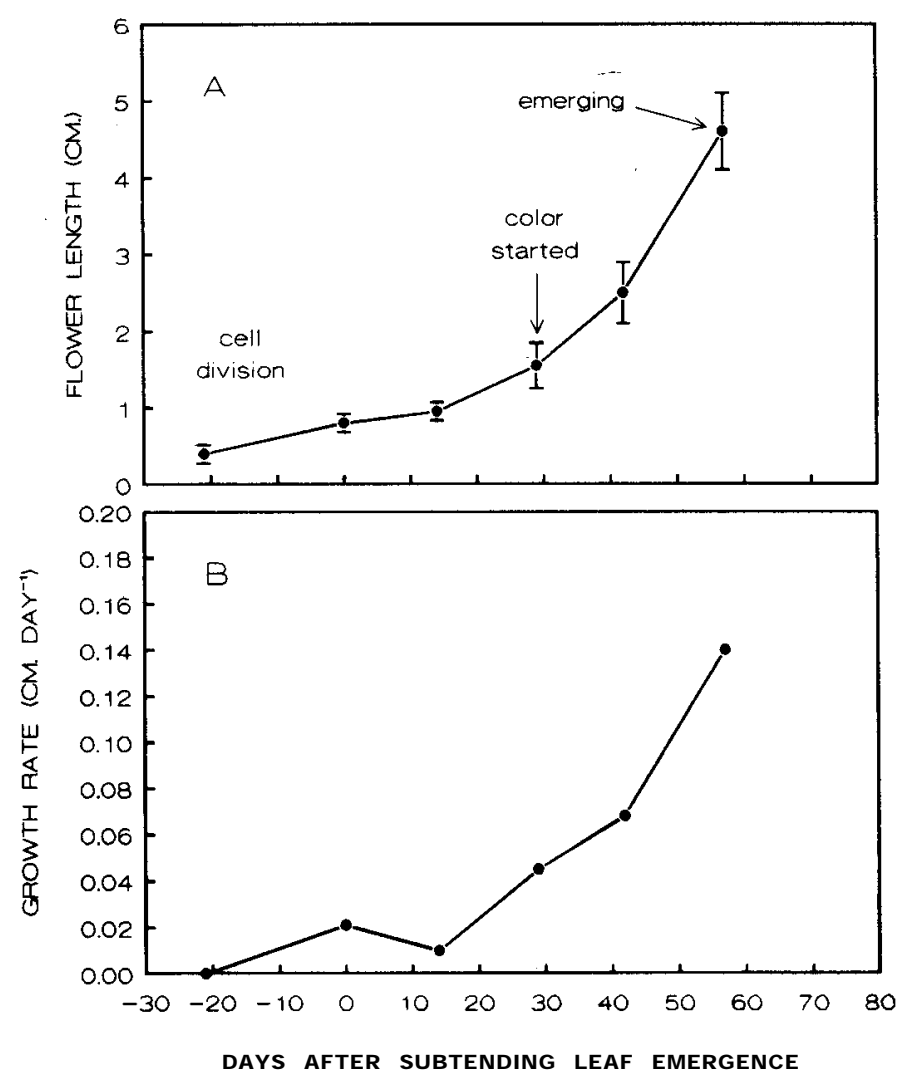

Fig. 1. 'Kaumana' anthurium flower growth inside the petiole base before and after subtending leaf emergence. The age of the flower bud was estimated as days before and after subtending leaf emergence. (A) Flower length, means $\pm \mathrm{SD}$; (B) flower growth rate (n $=8)$.

flower length. Flower growth rate reached $0.14 \mathrm{~cm} \cdot \mathrm{day}^{-1}$ as the flower increased from $50 \%$ to $100 \%$ of the length at emergence $(4.5$ to $5.0 \mathrm{~cm}$ ). At day 0, 56 ASLE (Table 1), the flower was poised to emerge from the petiole base (Fig. 2A).

Spathe development before emergence. The spathe was the first part of the flower to grow rapidly (Fig. 2B). Twenty-one days before leaf emergence (BLE), the spathe had reached a length of $0.3 \pm 0.1 \mathrm{~cm}$ and accounted for $75 \%$ of the total flower length. The spathe length started to increase and reached $0.7 \mathrm{~cm}$ when the subtending leaf was emerging. The growth rate was $0.019 \mathrm{~cm} \cdot$ day $^{-1}$ during this period, then declined following leaf emergence. During the flower stationary growth phase, the spathe remained 0.7 to $0.8 \mathrm{~cm}$ long, with a low growth rate $\left(0.007 \mathrm{~cm} \cdot \mathrm{day}^{-1}\right)$ from the day of leaf emergence. 

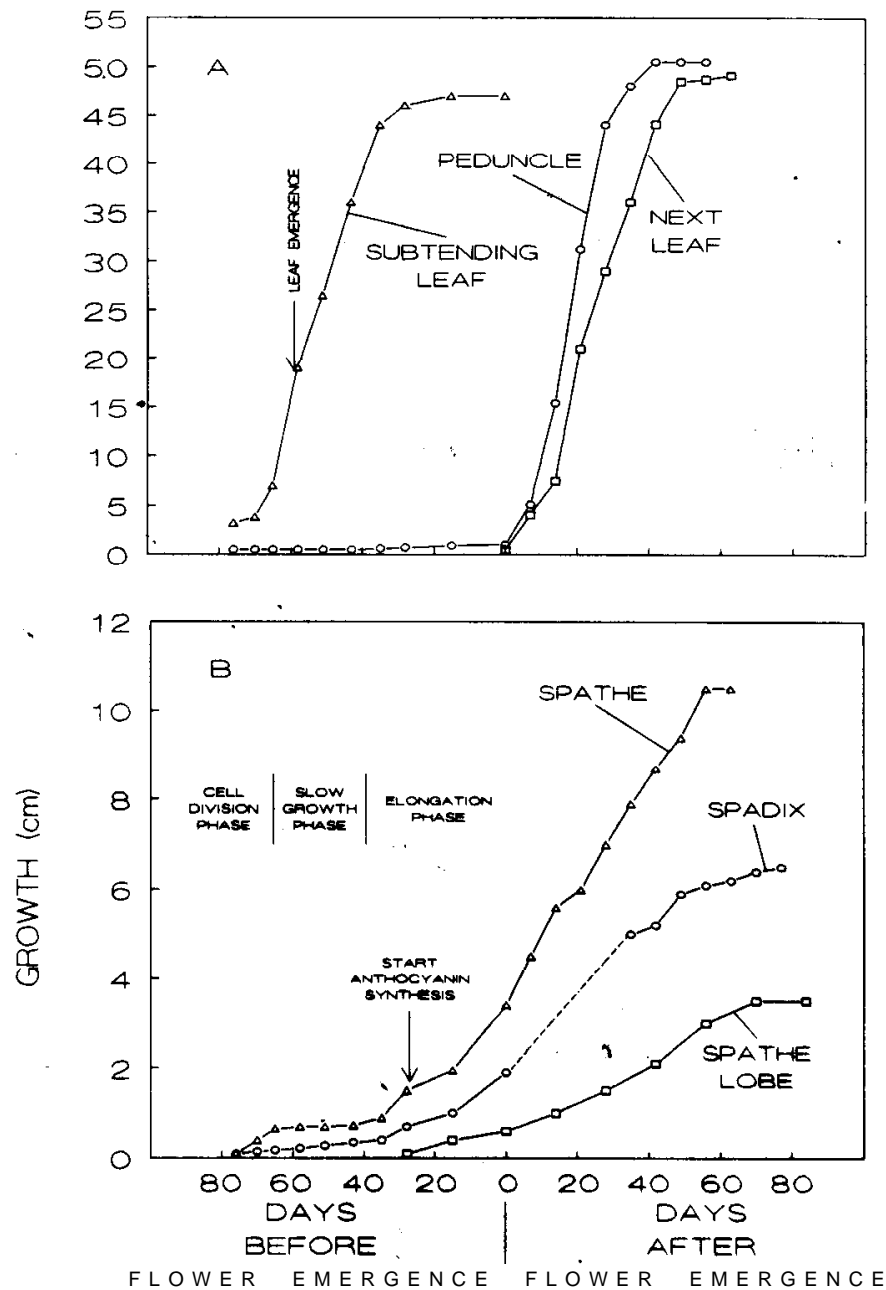

Fig. 2. 'Kaumana' anthurium growth of (A) peduncle and subtending leaf petiole and (B) spathe, spadix (dashed portion of line indicates no "measurement during interval), and lobe before and after emergence. Mean of measurements $(n=6)$.

After this slow growth period, spathe length increased from 0.7 $\mathrm{cm}$ to $1.3 \mathrm{~cm}$ in 14 days (Fig. 2B), with a growth rate of 0.036 $\mathrm{cm} \cdot \mathrm{day}^{-1}$ and reached $2 \mathrm{~cm}$ in another 14 days. During this period, spathe anthocyanin synthesis began at the middle of the spathe. At flower emergence, the growth rate was $0.07 \mathrm{~cm} \cdot \mathrm{day}^{-1}$.

Spathe lobe growth started 28 days BFE (Fig. 2B). Fourteen days BFE, the lobe length and width were about the same $(0.2$ $\mathrm{cm})$. No red pigment was visible in the lobes. At flower emergence, lobe length and width reached $=0.5 \mathrm{~cm}$ and $=20 \%$ of the final spathe length and $30 \%$ of the final spathe width.

Intensity of spathe redness increased rapidly as the spathe approached $50 \%$ of full development (Fig. 2B), 28 days BFE. Red first began to appear in the middle of the previously allwhite spathe, spreading upwards and downwards. When the flower reached $60 \%$ of its emergence length, $50 \%$ of the spathe was red; at flower emergence, $80 \%$ of it was red. The lobe portion was the last to redden. After the flower emerged from the petiole base, the lobes remained white for a further 7 to 10 days.

Spadix growth before emeigence. The spadix growth in the flower was slow and continuous inside the tightly furled spathe. No period of slow growth or decline in growth rate was observed (Fig. 2B). The spadix grew from $0.15 \mathrm{~cm}$ to $0.42 \mathrm{~cm}$ within 35 days, with a constant growth rate of $0.01 \mathrm{~cm} \cdot \mathrm{day}^{-1}$. Then the growth rate doubled, and the spadix length increased to $0.6 \mathrm{~cm}$ 28 days BFE.

Peduncle growth before emergence. The peduncle did not grow during the early stage of spadix and spathe development (Fig. $2 \mathrm{~A}$ and B), its length remained $<0.2 \mathrm{~cm}$ for the first 35 days (Fig. 2A). When the flower was $1.5 \mathrm{~cm}$ long (28 days $\mathrm{BFE})$, the peduncle began to grow. The peduncle elongated rapidly, with a growth rate of $0.021 \mathrm{~cm} \cdot \mathrm{day}^{-1}$, and the length reached $0.5 \mathrm{~cm} 14$ days BFE. The peduncle was $1.5 \mathrm{~cm}$ long at flower emergence (Fig. 2A).

Subtending leaf growth. Seven days after flower emergence (AFE), a new leaf (11 to $13 \mathrm{~cm}$ long) emerged from the old leaf sheath axil. The new leaf sheath elongated very slowly and reached its maximum length of $15 \mathrm{~cm}$ at day 21 from previous flower emergence. Seven days after new leaf emergence, the petiole reached its highest elongation rate of $1.9 \mathrm{~cm} \cdot$ day $^{-1}$ (Fig. $2 \mathrm{~A}$ ), which then declined slightly for the next 7 days. As the petiole approached its full length, $=21$ days after leaf emergence (ALE) and 42 days AFE, the growth rate declined to 1.0 $\mathrm{cm} \cdot \mathrm{day}^{-1}$. The leaf petiole continued to elongate very slowly for another 14 to 21 days and stopped 42 days ASLE (Fig. 3) and 56 days AFE (Fig. 2A).

The olive-brown young leaf (14 days ALE) had a negative measured net photosynthesis rate (Table 2). Measured net photosynthesis rate increased as the leaf blade matured. The highest measured net photosynthesis rate occurred 42 days ALE, when the subtending leaf was mature and dark green (Table 2).

Flower-growth after emergence. The average length of a flower at emergence from the leaf petiole base was $4.5 \pm 0.5 \mathrm{~cm}$ (Fig.

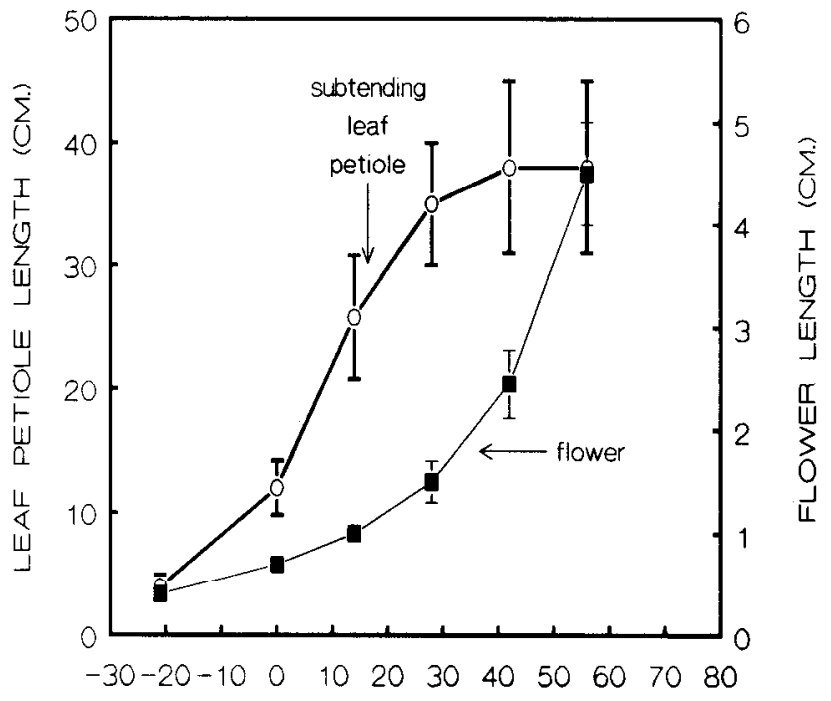

DAYS AFTER SUBTENDING LEAF EMERGENCE

Fig. 3. 'Kaumana' anthurium subtending leaf petiole growth and the flower growth inside the petiole base. Means $\pm S D(n=8)$.

Table 2. Measured net photosynthesis rate of developing anthurium leaves after their emergence.

\begin{tabular}{clcc}
\hline \hline $\begin{array}{c}\text { Leaf } \\
\text { age } \\
\text { (days) }\end{array}$ & Color & $\begin{array}{c}\text { Area } \\
\left(\mathrm{cm}^{2}\right)\end{array}$ & $\begin{array}{c}\text { Measured net } \\
\text { photosynthesis' } \\
\left(\mathrm{CO}_{2}, \mathrm{mg} \cdot \mathrm{m}^{-2} \cdot \mathrm{min}^{-1}\right)\end{array}$ \\
\hline 14 & Olive brown & $54 \pm 29$ & $-1.08 \pm 1.08$ \\
28 & Green & $139 \pm 11$ & $2.28 \pm 0.72$ \\
42 & Dark green & $157 \pm 9$ & $6.30 \pm 0.54$ \\
\hline
\end{tabular}

${ }^{\mathrm{z}}$ Means $\pm \mathrm{SD}(\mathrm{n}=3)$. 
1A). The growth curve for the peduncle stem was sigmoid (Fig. 2A). Seven days after emergence, the flower peduncle growth rate was $1.4 \mathrm{~cm} \cdot \mathrm{day}^{-1}$, and by day 21 , the peduncle had reached the maximum growth rate of $2.2 \mathrm{~cm} \cdot \mathrm{day}^{-1}$. The growth rate gradually declined as the peduncle approached its full length 42 to 50 days AFE (Fig. 2A).

The spathe growth curve was a double sigmoid (Fig. 2B). Spathe growth rate was initially rapid, with a maximum growth rate of $0.17 \mathrm{~cm} \cdot \mathrm{day}^{-1}$. Fourteen days AFE, the growth rate declined. By day 21, the spathe had almost stopped growing, with a growth rate of only $0.07 \mathrm{~cm} \cdot$ day -1 . The slow growth rate lasted for $=7$ days and was followed by a second peak of growth with a rate of $0.14 \mathrm{~cm}$-day-1, 35 to 42 days AFE. This was followed by a second decline in growth rate. This second decline continued to day 63 , when the spathe reached its full length.

The unfurling of the spathe occurred 35 days AFE (Fig. 2B). At this stage, the spadix appeared in the middle of the spathe and became measurable. The growth of the spadix was very fast, with a maximum growth rate of $0.086 \mathrm{~cm} \cdot$ day $^{-1}$ at day 49 AFE (Fig. 4B). The growth rate declined rapidly to zero after this peak and stopped at about day 77 (Fig. 4B).

During spadix elongation (Fig. 4), flower maturation progressed from the base to the apex. At day 35, 0 to $20 \%$ of the minute flowers on the spadix were mature, while 14 days later, $50 \%$ of the flowers had matured (Fig. 4A). The spadix matured an additional $20 \%$ of the flowers in the following 14 days and reached full maturity 77 days AFE.
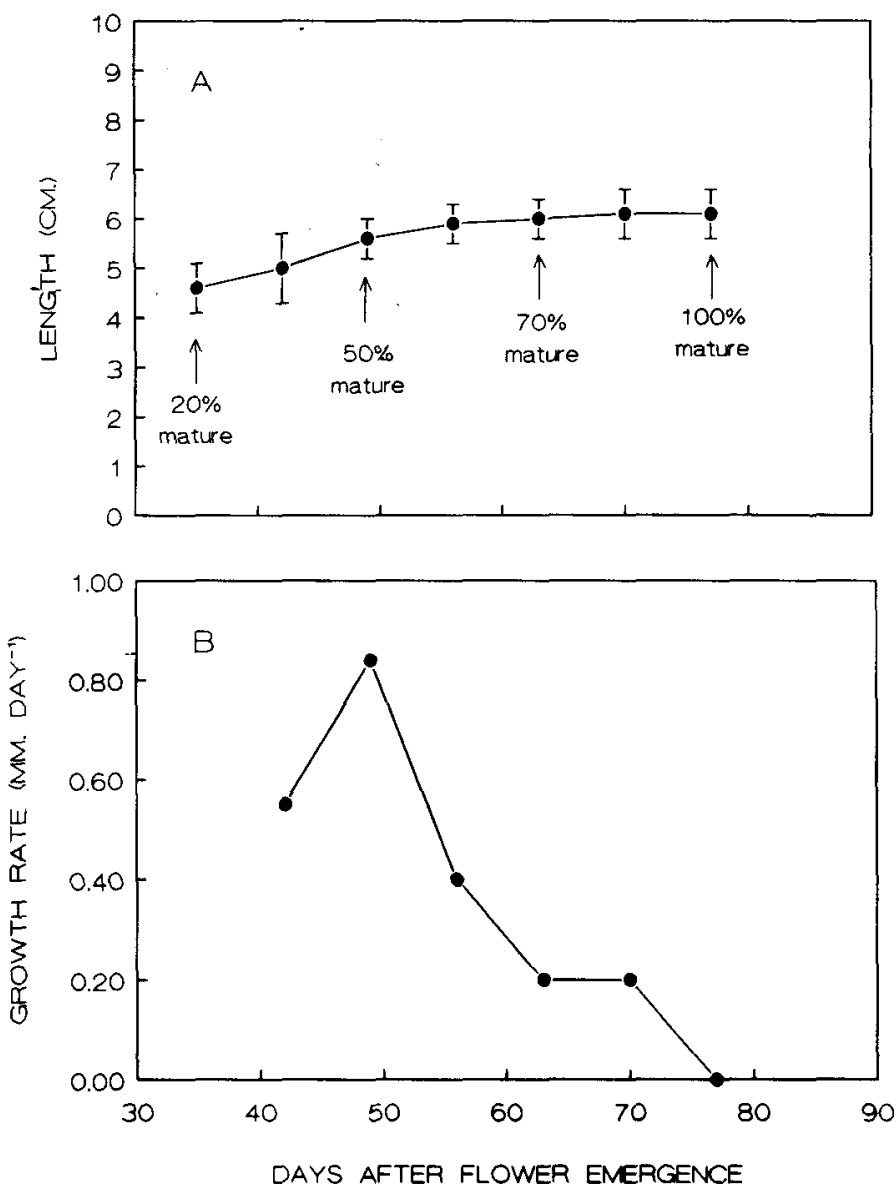

Fig. 4. 'Kaumana' anthurium flower spadix growth after unfurling of the spathe. (A) Spadix growth. (B) Spadix growth rate. Means $\pm \mathrm{SD}(\mathrm{n}=8)$.
Lobe growth after flower emergence to day 42 was constant, with a growth rate of $0.036 \mathrm{~cm} \cdot$ day $^{-1}(\mathrm{Fig}$. 2B). The lobe growth rate then doubled until day 56 and gradually declined to zero as the lobes matured.

Effect of subtending leaf removal on flower growth inside petiole base. Removal of the young subtending leaf ( $=7$ to 14 days ASLE) resulted in emergence of the flower 18 days earlier than in the control (Table 3). Removal of a light-green leaf 28 to 35 days ASLE resulted in flower emergence occurring 11 days sooner than the control. Removal of an older, subtending leaf (42 to 56 days ASLE) had little effect on flower emergence time.

\section{Discussion}

The anthurium flower is unique in consisting of peduncle, spathe, and spadix (Higaki et al., 1984; Paull and Goo, 1985). The spathe actually is a modified leaf and the true flowers are born on the spadix (Higaki et al., 1984). Flower growth before emergence consisted of three phases: a cell division phase, a slow growth phase, and finally an elongation phase. The cell division phase was the earliest phase of flower growth after initiation and occurred $=80$ days BFE (Fig. 2). Following this phase, there was a slow flower bud growth phase (Fig. 3), when the subtending leaf petiole was in the fast elongation period and the leaf was not fully expanded (Fig. 2A). This slow growth phase might be the "dormancy" phase for Anthurium described by Christensen (1971). Twenty-eight days ASLE (Table 1), as the leaf unfurled and became photosynthetically positive (Table 2 ) and petiole elongation gradually slowed, flower bud elongation recommenced (Fig. 3).

Young, immature leaves had a negative net photosynthesis rate (Table 2), possibly because the photosynthesis system had not developed and maintenance respiration needs were greater than photosynthesis, the cells still being heterotrophic (Baker, 1985). Young, developing anthurium leaves were apparently stronger sinks than other parts of the plant, including the immature flower. The fast growth of the subtending leaf acted as a storage sink, depriving the immature flower of nutrients and slowing the growth rate. When the subtending leaf had a positive net photosynthesis rate, it also became a source for the other sink, the flower. Removal of young subtending leaves therefore changed the source and sink relationship, allowing the immature flower inside the petiole base to grow and promote earlier emergence (Table 3). The subsequent elongation phase started $=42$ days BFE and continued AFE (Fig. 2). Removal of the subtending leaf may have commercial possibilities, enabling growers to promote a short-term increase in flower production to meet a high: demand period.

Klapwijk and van der Spek (1988) concluded that the Neth-

Table 3. Effect of subtending leaf removal at various times after emergence on subsequent flower emergence. Emergence of control flowers without subtending leaf removal was regarded as day $0 .{ }^{z}$

\begin{tabular}{lccc}
\hline \hline $\begin{array}{c}\text { Leaf blade } \\
\text { removal } \\
\text { after } \\
\text { emergence } \\
\text { (days) }\end{array}$ & $\begin{array}{c}\text { Flower } \\
\text { emergence } \\
\text { relative } \\
\text { to control } \\
\text { (days) }\end{array}$ & $\begin{array}{c}\text { Length of structure when } \\
\text { control flowers emerged } \\
\text { Peduncle } \\
(\mathrm{cm})\end{array}$ & $\begin{array}{c}\text { Spathe } \\
\text { (cm) }\end{array}$ \\
\hline $7-14$ & $-18 \pm 4$ & $21.5 \pm 16.9$ & $6.2 \pm 0$. \\
$28-35$ & $-11 \pm 2$ & $12.8 \pm 7.3$ & $5.5 \pm 0$. \\
$42-50$ & $-4 \pm 4$ & $3.4 \pm 1.5$ & $4.3 \pm 0$. \\
No removal & $0 \pm 2$ & $2.8 \pm 0.4$ & $4.3 \pm 0$.
\end{tabular}

${ }^{\mathrm{z}}$ Means \pm SD $(\mathrm{n}=6)$. 
erlands' maximum production of anthuriums in late June was related to the high leaf production in February and March. They suspected that the minimum production in March was the result of a severe abortion rate of flower buds in December. Dead flower buds were occasionally found in this study at the rapid elongation phase. The abortion rate found in flower buds in the Netherlands was associated with lower solar radiation received in November to January. The results suggest a changed relationship between source and sink caused the minimum production in the Netherlands and the dead flower buds found in this study. The modification of the source-sink relationship could also be related to the content of plant growth regulators and/or tissue sensitivity to growth regulators.

Yields of anthuriums vary from 3.4 to 7.6 flowers per plant per year (Kamemoto et al., 1986). This means a new flower appears every 48 to 107 days. An earlier report (Kamemoto and Nakasone, 1963) found there were 56 days between flowers for the cultivar Kaumana. Under the conditions used in our study, a new flower appeared every 75 days. Variation in flower yield is significantly influenced by temperature and solar radiation (Leffring, 1975; Kamemoto et al., 1986; Klapwijk and van der Spek, 1988) and could explain the variation in flower appearance rate for the cultivar Kaumana. 'Marian Seafurth' flowering cycle was 20 days shorter than for 'Kaumana' in preliminary tests, and leaf and flower emergence were separated by 35 and 55 days for 'Marian Seafurth' and 'Kaumana', respectively. This cultivar difference could be due to more rapid leaf plastrochron duration or, as preliminary results suggest, a shorter flower growth stationary phase before flower emergence. The role of source-sink relationship may be significant in regulating flower production rate. Source-sink relationships may explain some of the genetically related flower yield differences found between cultivars (Kamemoto et al., 1986).

This study provides basic information about anthurium flower growth and development and thus provides a basis for investigating the bleach problem, a disorder that appears to be related to growth interruption. The period 28 days BFE, when lobe and spadix growth and spathe anthocyanin development occur, could be a growth stage when growth disruption would be most severe. Spathe lobes were the last to develop (Fig. 2) and probably would be the most sensitive to the bleach problem. But whether it is sensitive before or after emergence is unknown. Factors that disturb anthocyanin production at this period may lead to the bleach condition. A deformed spathe and spadix maybe the results of uneven cell division; therefore, the period 60 to 80 days before flower emergence may be an alternate critical period.

\section{Literature Cited}

Baker, N.R. 1985. Energy transduction during leaf growth, p. 112125. In: N.R. Baker, W.J. Davies, and C.K. Ong (eds.). Control of leaf growth. Sot. Expt. Biol. Seminar Ser. no. 27. Cambridge University Press, London.

Bushe, B. C., W.T. Nishijima, A.H. Hara, and D.M. Sate. 1987. Identifying anthurium flower injuries. HITAHR Brief 073.

Christensen, O.V. 1971. Morphological studies on the growth and flower formation of Anthurium scherzerianum Schott and Anthurium andraeanum Lind. Tidsskrift for Planteavl. 75:793-798.

Erickson, R.O. 1976. Modeling of plant growth. Annu. Rev. Plant Physiol. 27:407-434.

Hawaii Agricultural Statistics Service. 1988. Statistics of Hawaiian agriculture. Hawaii Agr. Statistics Serv. Honolulu.

Higaki, T. and D.P. Watson. 1967. Anthurium-culture in Hawaii. Univ. of Hawaii. Hawaii Coop. Ext. Serv. Circ. 420.

Higaki, T., H.P. Rasmussen, and W.J. Carpenter. 1984. A study of some morphological and anatomical aspects of Anthurium andraeanum Lind. Univ. of Hawaii, CTAHR. no. 30.

Jensen, W.A. 1962. Botanical histochemistry: Principles and practices. W.H. Freeman \& Co., San Francisco.

Kamemoto, H. and H.Y. Nakasone. 1963. Evaluation and improvement of anthurium clones. Hawaii Agr. Expt. Sta., Univ. of Hawaii. Tech. Bul. 58.

Kamemoto, H., J. Kunisaki, M. Aragaki, and T. Higaki. 1986. Evaluation of Anthurium accessions. College of Trop. Agr. and Human Resources, Univ. of Hawaii. Res. Ext. Ser. 069.

Klapwijk, D. and H.J.H. van der Spek. 1988. Development rate, flower growth and production of Anthurium. Netherlands J. Agr. Sci. 36:219224.

Leffring, L. 1975. Influence of climatic conditions on growth and flower yield of Anthurium andreanum. Acts Hort. 51:63-68.

Marutani, M. 1984. Cytological and biochemical analyses of Anthurium andraeanum and closely related taxa. PhD Diss., Univ. of Hawaii.

Nishijima, W.T. 1981. Update report: Bleaching problem of anthurium. College of Trop. Agr. and Human Resources. Coop. Ext. Serv., Univ. of Hawaii at Manoa. Unpublished report.

Paull, R.E. and T.C. Goo. 1985. Ethylene and water stress in the senescence of cut anthurium flowers. J. Amer. Soc. Hort. Sci. 110:8488.

Royal Horticultural Society. 1966. RHS colour chart. The Royal Horticultural Society, London.

Walker, P.N. and M.R. Smith. 1978. Machine logic requirements of an anthurium harvester. Trans. Amer. Soc. Agr. Eng. 21:10401044. 